\title{
Australian Journal of

\section{Upland rice gas exchange, nutrient uptake and grain yield as affected by potassium fertilization and inoculation of the diazotrophic bacteria Serratia spp.}

\author{
Adriano S. Nascente ${ }^{1 *}$, Marta Cristina C. Filippi ${ }^{1}$, Thatyane P. Sousa ${ }^{2}$, Amanda A. Chaibub ${ }^{3}$, Alan Carlos A. \\ Souza ${ }^{4}$, Anna Cristina Lanna ${ }^{1}$
}

${ }^{1}$ Empresa Brasileira de Pesquisa Agropecuaria (EMBRAPA), Centro Nacional de Pesquisas de Arroz e Feijao, P.O. Box 179, Highway 462, km 12, Santo Antônio de Goiás, State of Goiás, 75.375-000, Brazil

${ }^{2}$ Escola de Agronomia, Universidade Federal de Goiás, Goiânia - GO, Brazil. 74.690-900

${ }^{3}$ Departamento de Fitopatologia, Universidade de Brasília, Brasília - DF, Brazil. 70.910-900

${ }^{4}$ Departamento de Fitopatologia, Universidade Federal de Lavras, Lavras - MG, Brazil. 37200-000

\section{*Corresponding author: adriano.nascente@embrapa.br}

\begin{abstract}
Potassium (K) is the second most uptaken nutrient by upland rice crops. Beneficial microorganisms, such as Rhizobacteria participate in different processes that affect transformation of soil nutrients, making them available to plants. However, there are no information about the use of Rhizobacteria and different rates of $\mathrm{K}$ fertilization in this crop. To elucidate this interaction, the objective of this study was to determine the effect of the rhizobacteria Serratia spp. strain BRM 32114 and doses of K at sowing fertilization on upland rice development. The experimental design was a complete randomized block in a factorial $4 \times 2$ scheme with four replications, under no-tillage systems conducted in the Brazilian Cerrado during 2015/16 and 2016/17 growing seasons. The treatments consisted of four $\mathrm{K}_{2} \mathrm{O}$ doses $\left(0,20,40\right.$ and $\left.60 \mathrm{~kg} \mathrm{~h}^{-1}\right)$ without or with rhizobacteria applied three times in the field (on the seeds, sprayed over the soil, seven days after sowing and sprayed on the plants, 14 days after sowing). Biomass production, gas exchange, nutrient content in leaves and grain, yield components and grain yield were evaluated. The use of BRM 32114 applied in soil with high levels of $\mathrm{K}$ provided increase in the contents of $\mathrm{P}, \mathrm{Ca}, \mathrm{Mg}$, Fe and $\mathrm{Zn}$ in rice leaves. The results showed enhances in plant biomass (7.2\%), the number of panicles per plant (10\%), and the grain yield of upland rice (16.3\%). Therefore, our results allow inferring that the use of microorganism BRM 32114 provided significant improvements in rice growth/development, which resulted in higher grain yield over two consecutive growing seasons under field conditions. It showed that the bioagent Serratia spp. is promising to be incorporated into crop systems.
\end{abstract}

Keywords: Oryza sativa; bioagent; rhizobacteria; fertilizer; growth promoter; sustainable development.

Abbreviations: PBRM_Plant Beneficial Rhizospheric Microrganisms, IAA_indole acetic acid, A_photosynthesis, E_transpiration, gs_stomata conductance, PGPR_Plant Growt-Promoting Bacteria, Ci_internal $\mathrm{CO}_{2}$ concentration, Tleaf_leaf temperature, IRGA_Infra Red Gas Analyzer, PPFD_Photon Flux Density Photosynthetic Active.

Introduction

Rice is one of the most important food crops in the world with a global per capita consumption around $57 \mathrm{~kg} \mathrm{yr}^{-1}$. Therefore, the increase in total consumption should follow the rate of population growth (Chakraborty et al., 2017). It is cultivated in 159 million hectares (Mha), representing 11\% of cultivated area, with an annual production of 703.8 million tons (Mt) of paddy. From the total area, 6 million ha is cultivated with upland, $9 \%$ in Asia, $46 \%$ of Latin America including the Caribbean countries, and $47 \%$ of West Africa (Kikuta et al., 2016).

Agriculture sustainability can be defined as the common face of agronomic, ecologic, economic and social factors. However, food production in sustainable systems faces the challenge of increasing fertilizer application so that the productivity limit can be advanced. Also, the integrity of the environment must be preserved, protecting ecosystems and biodiversity (Meena et al., 2017).

There are many studies showing significant increase in rice grain yield due to $\mathrm{K}$ fertilization (Fageria et al., 1990; Fageria, 2000; Farinelli et al., 2004; Carmeis Filho et al., 2017). For upland rice plants, $K$ is essential for growth and development. It is extracted from the soils in large amounts, such as $245 \mathrm{~kg} \mathrm{ha}^{-1}$ (Slaton et al., 2009; Fageria et al., 2010; Fageria et al., 2011b). The principal roles of $\mathrm{K}$ in plants are mainly the osmotic potential regulation, acting in the transporters mechanism in the cell membrane of root tissues, increasing root development in rice (Fageria et al., 2010; Fageria et al., 2011a; Clover and Mallarino, 2013) and accumulating in the shoots (Crusciol et al., 2016).

Although great amounts of $\mathrm{K}$ is required, there is a wish to increase crop grain yield with a significant reduction of 
fertilizer and pesticides (Bashan et al., 2014), once this reduction is environmentally friendly and yield efficient.

In this sense, adopting Plant Beneficial Rhizospheric Microrganisms (PBRM) is one practice that can reduce the negative environmental impact caused by excess chemical fertilizers and agrochemicals, playing an important role in sustainable agriculture (Vejan et al., 2016). In microflora, PBRMs have important molecules within their cell constitution, such as flagellin (protein constituent of flagella) and lipopolysaccharides (LPS, cell membrane constituents) (Kaschuk et al. 2010). These components are recognized by the plant as metabolism activators. Thus, the benefits of the interaction between PGPR and plants can be direct, such as growth promotion, since some bacterial groups produce phytohormones such as indole acetic acid (IAA), cytokinins and gibberellins, or solubilizing phosphorus and producing siderophores (Spaepen et al. 2009; Ahemad and Kilbret 2014). Among the indirect benefits is the protection against pathogens, such as the induction of resistance and direct antagonism.

These bacteria are basic components of food webs and play crucial and unique roles in the agricultural production system (Anees et al. 2010). Several bacterial genera are currently being studied as biostimulants and biofertilizers, such as Azospirillum strain AbV5 (Isawa et al., 2010), Gluconacetobacter (Muthukumarasamy et al., 2005), Herbaspirillum, Burkholderia (Baldani et al., 2000) and Pseudomonas (Yao et al., 2010), Bacillus, Serratia, Paenibacillum, Enterobacter and Klebsiella (Spaepen et al., 2009).

Research focusing on the use of rhizobacteria in rice crops selected promising rhizobacteria isolates which stood out mainly due to their increased biomass production and disease resistance (Filippi et al. 2011; Silva et al. 2012; França et al. 2015). These rhizobacteria was tested under greenhouse conditions and showed that Serratia ssp, strain BRM 32114, promoted gas exchange, nutrients accumulation and biomass production, which differed from the control (untreated plants) in upland rice plants (Nascente et al., 2017). Effects of this rhizobacteria can be affected by mineral nutrition of the plants (Ahemad and Kilbret, 2014). However, there is still no information combining upland rice plant, rhizobacteria and potassium fertilization under field conditions of a Tropical region. Therefore, the objective of this study was to determine the effect of the rhizobacteria Serratia spp., strain BRM 3214, and doses of $\mathrm{K}$ at sowing fertilization on upland rice by biomass production, gas exchange, nutrient content in leaves and grain, yield components and grain yield under notillage systems in a Tropical Region.

\section{Results}

\section{Gas exchange of rice plants as affected by rhizobacteria}

There was no difference in gas exchange parameters for upland rice plants grown in the presence and absence of Serratia spp. (strain BRM32114) and at different K levels (Table 2). For photosynthetic rate (A), there was interaction between BRM32114 and evaluation time, growing season and evaluation time with growing season (Table 3 ). Thus, BRM32114-treated upland rice presented greater $A$ and $E$ at the reproductive stage in growing season 2015/16 and higher A, E and gs at the vegetative phase in growing season 2016/17.

\section{Nutrient content in rice leaves}

There was single effect of BRM32114 on N and Fe content in upland rice leaves (Table 4). Nitrogen content was increased in no treated plants (without BRM 32114); while Fe content increased in BRM 32114-treated plants. There was interaction between BRM32114 and growing season for $\mathrm{P}$, $\mathrm{Ca}, \mathrm{Mg}$ and $\mathrm{Zn}$ content in leaves of upland rice. So, in 2015/16, the Zn content was higher in BRM 32114-treated plants compared to no treated plants. In 2016/17, BRM 32114-treated plants presented higher values of $\mathrm{P}, \mathrm{Ca}$ and $\mathrm{Mg}$ content. There was interaction between $\mathrm{K}$ rates and growing season for $K$ content in rice leaves (Fig. 2).

\section{Plant biomass, yield components and grain yield of upland rice plants}

The use of BRM32114 provided increases in plant biomass, number of panicle per plant and grain yield of upland rice (Table 5). Number of grains per panicle and mass of 1000 grains of upland rice plants were not affected by use of BRM 32114. The $\mathrm{K}$ levels had no effect on these parameters.

Regarding growing season effect, in 2016/17, plants presented higher biomass, number of panicle per plant, number of grains per panicle and grain yield than 2015/16. BRM 32114-treated rice yield was $4921 \mathrm{~kg} \mathrm{ha}^{-1}$ compared to $3983 \mathrm{~kg} \mathrm{ha}^{-1}$ in no treated plants at the growing season $2016 / 17$. For the growing season 2015/16, these values were $2663 \mathrm{~kg} \mathrm{ha}^{-1}$ with BRM 32114 and $2363 \mathrm{~kg} \mathrm{ha}^{-1}$ without BRM 32114 (Table 5).

\section{Nutrient content in rice grains}

Untreated plants presented higher $\mathrm{N}$ content in rice grains (Table 6). In growing season 2015/16, the contents of $P, K$, $\mathrm{Ca}, \mathrm{Mg}$ and $\mathrm{Fe}$ in grains were higher in BRM 32114-treated plants. There was interaction between BRM32114 and growing season for $\mathrm{Cu}, \mathrm{Mn}$ and $\mathrm{Zn}$, being the highest content of them observed in the grains of no treated plants, in $2016 / 2017$.

\section{Discussion}

Researches at Embrapa Rice and Beans found that application of on Serratia spp. (a gram negative anaerobic bacteria) strain BRM 32114, produces IAA, cellulase and siderophores, which enhance resistance, photosynthetic rate, root development, dry matter and uptake/accumulation nutrients in rice shoots, (Nascente et al., 2017; Sperandio et al., 2017). In our trials, we describe an exceptional grain yield increase promoted by BRM32114 under field conditions independent from $\mathrm{K}$ doses applied. Our results show that $K$ rates $\left(20,40\right.$ and $\left.60 \mathrm{~kg} \mathrm{ha}^{-1}\right)$ presented no effect on the evaluated parameters. This is probably because in both growing seasons the $\mathrm{K}$ content in the soil was very high $\left(101,3 \mathrm{mg} \mathrm{dm}^{-3}\right.$ and $97 \mathrm{mg} \mathrm{dm}^{-3}$ in 2015/16 and 2016/17, respectively) (Table 1) (Sousa and Lobato, 2004). So, the soil with $0 \mathrm{~kg} \mathrm{ha}^{-1}$ of $\mathrm{K}$ did not show any deficiency or unbalanced evidence. Corroborating this information, Zaratin et al. (2004) observed that K fertilization 
Table 1. Chemical and physical properties of the soil at the beginning of the trial.

\begin{tabular}{|c|c|c|c|c|c|c|c|}
\hline \multicolumn{8}{|c|}{ Growing season $2015 / 2016$} \\
\hline Depth & $\mathrm{Ca}$ & $\mathrm{Mg}$ & $\mathrm{H}+\mathrm{Al}$ & SOM $^{1}$ & $P$ & $\mathrm{~K}$ & $\mathrm{pH}\left(\mathrm{H}_{2} \mathrm{O}\right)$ \\
\hline (m) & \multicolumn{3}{|c|}{ - $\mathrm{mmol}_{\mathrm{c}} \mathrm{dm}^{-3}$} & $\mathrm{~g} \mathrm{dm}^{-3}$ & \multicolumn{3}{|c|}{$----m g d^{-3}---$} \\
\hline $0-0.20$ & 18.0 & 13.3 & 24.0 & 32.7 & 9.9 & 101.3 & 5.9 \\
\hline Depth & $\mathrm{Cu}$ & $\mathrm{Zn}$ & $\mathrm{Fe}$ & $\mathrm{Mn}$ & Clay & Silt & Sand \\
\hline (m) & ---- & ----- & & ------ & --- & $--\mathrm{g} \mathrm{kg}^{-1}$ & ------------ \\
\hline $0-0.20$ & 0.8 & 4.6 & 20.5 & 10.1 & 480 & 226 & 294 \\
\hline \multicolumn{8}{|c|}{ Growing season $2016 / 2017$} \\
\hline Depth & $\mathrm{Ca}$ & $\mathrm{Mg}$ & $\mathrm{H}+\mathrm{Al}$ & SOM $^{1}$ & $\mathrm{P}$ & $\mathrm{K}$ & $\mathrm{pH}\left(\mathrm{H}_{2} \mathrm{O}\right)$ \\
\hline (m) & \multicolumn{3}{|c|}{ - } & $\mathrm{g} \mathrm{dm}^{-3}$ & \multicolumn{3}{|c|}{$---\mathrm{mg} \mathrm{dm}^{-3}---$} \\
\hline $0-0.20$ & 10.7 & 10.9 & 31.0 & 42.22 & 12.6 & 97 & 5.5 \\
\hline $\begin{array}{l}\text { Depth } \\
\text { (m) }\end{array}$ & $\mathrm{Cu}$ & $\begin{array}{l}\mathrm{Zn} \\
\mathrm{mg} d r\end{array}$ & $\mathrm{Fe}$ & $\mathrm{Mn}$ & Clay & Silt & Sand \\
\hline $0-0.20$ & 1.2 & 8.1 & 31.0 & 12.2 & 520 & 180 & 300 \\
\hline
\end{tabular}

'SOM - soil organic matter.
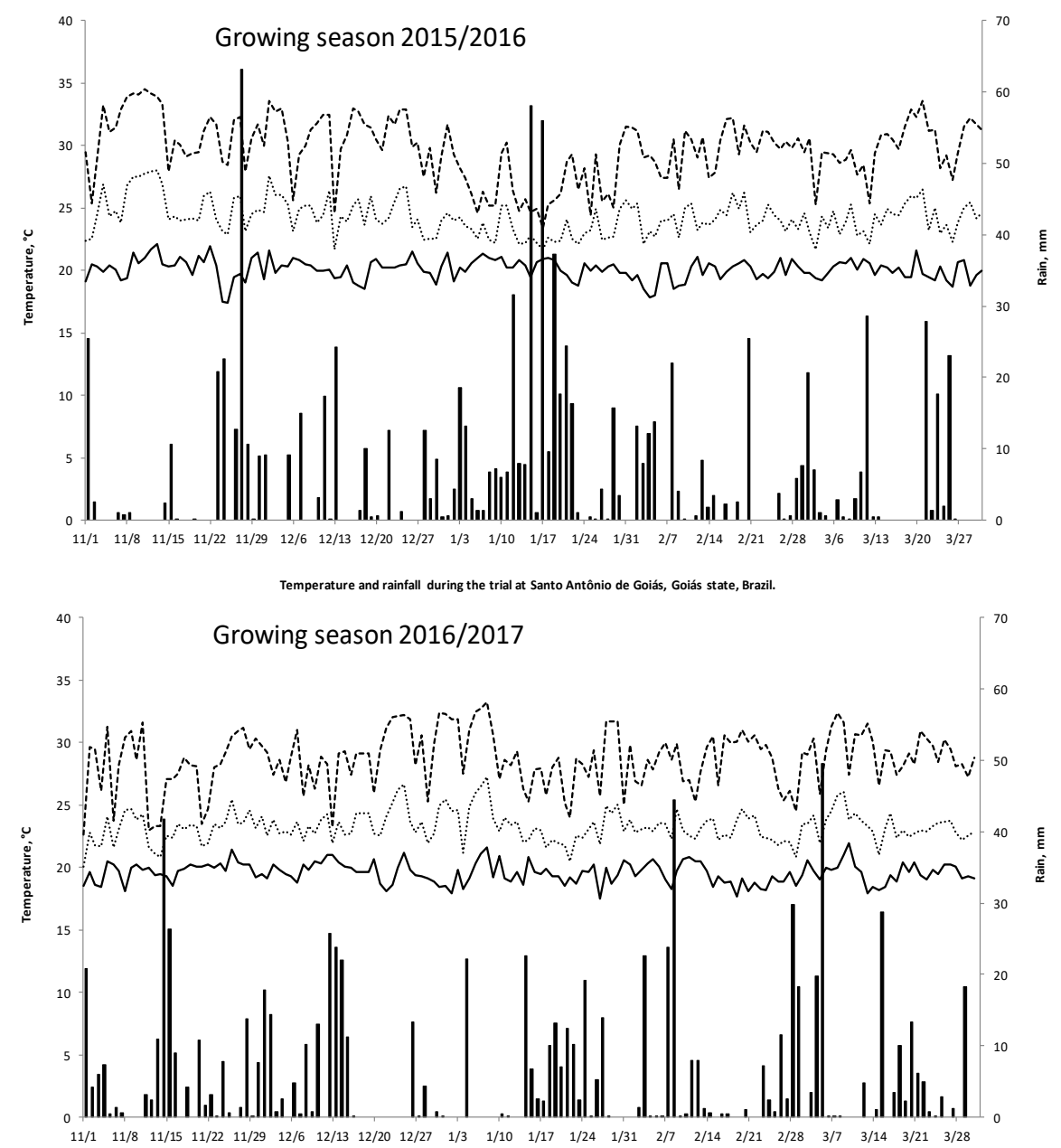

Temperature and rainfall during the trial at Santo Antônio de Goiás, Goiás state, Brazil.

Fig 1. Maximum ( $T$ maximum), minimum ( $T$ minimum) and average ( $T$ average) temperatures and rainfall during the trial period of upland rice grown under a no-tillage system in the experimental fields of Santo Antônio de Goiás in the 2015/16 and 2016/17 growing seasons. 
Table 2. Potassium rates and Serratia spp. isolated BRM 321114 with or without inoculation in rice seeds as affecting photosynthesis (A), transpiration (E), stomatal conductance (gs), internal $\mathrm{CO}_{2}$ concentration (Ci) and leaf temperature (Tleaf) of rice plants in two evaluation times at vegetative and reproductive phase of rice development. Santo Antônio de Goiás, growing season 2015/2016 and 2016/2017.

\begin{tabular}{|c|c|c|c|c|c|}
\hline Factors & $A$ & $E$ & gs & $\mathrm{Ci}$ & Tleaf \\
\hline Serratia & $\mu \mathrm{mol} \mathrm{CO} \mathrm{m}^{-2} \mathrm{~s}^{-1}$ & $\mathrm{mmol} \mathrm{H}_{2} \mathrm{O} \mathrm{m}^{-2} \mathrm{~s}^{-1}$ & $\mathrm{~mol} \mathrm{H}_{2} \mathrm{O} \mathrm{m}^{-2} \mathrm{~s}^{-1}$ & vpm & ${ }^{\circ} \mathrm{C}$ \\
\hline With & $25.03^{\text {ns }}$ & $6.00^{\text {ns }}$ & $1.01^{\mathrm{ns}}$ & $288^{\mathrm{ns}}$ & $30.00^{\mathrm{ns}}$ \\
\hline Without & 24.82 & 5.95 & 1.00 & 289 & 29.81 \\
\hline \multicolumn{6}{|l|}{ Evaluation time } \\
\hline Vegetative & $26.42 \mathrm{a}$ & $6.27 \mathrm{a}$ & $1.07 \mathrm{a}$ & 296 a & $29.33 b$ \\
\hline Reproductive & $23.42 \mathrm{~b}$ & $5.69 \mathrm{~b}$ & $0.94 \mathrm{~b}$ & $282 \mathrm{~b}$ & $30.59 a$ \\
\hline \multicolumn{6}{|l|}{ Growing season } \\
\hline $2015 / 2016$ & $22.61 \mathrm{~b}$ & $5.15 b$ & $0.56 \mathrm{~b}$ & $268 \mathrm{~b}$ & $31.10 \mathrm{a}$ \\
\hline $2016 / 2017$ & $27.24 \mathrm{a}$ & $6.80 \mathrm{a}$ & $1.45 \mathrm{a}$ & 310 a & $28.71 \mathrm{~b}$ \\
\hline Factors & \multicolumn{5}{|c|}{ ANOVA (F Probability) } \\
\hline$\overline{\text { Serratia }(S)}$ & 0.4807 & 0.7935 & 0.9190 & 0.7163 & 0.5054 \\
\hline Potassium rates (K) & 0.4579 & 0.9141 & 0.3771 & 0.3340 & 0.9771 \\
\hline Evaluation time (ET) & $<0.001$ & 0.0010 & 0.0129 & $<0.001$ & $<0.001$ \\
\hline Growing season (GS) & $<0.001$ & $<0.001$ & $<0.001$ & $<0.001$ & $<0.001$ \\
\hline $\mathrm{S} \times \mathrm{K}$ & 0.0510 & 0.6015 & 0.1839 & 0.4103 & 0.8614 \\
\hline$S \times E T$ & 0.0268 & 0.1394 & 0.1895 & 0.3278 & 0.0137 \\
\hline$S \times G S$ & 0.0040 & 0.0517 & 0.8881 & 0.0111 & 0.7984 \\
\hline $\mathrm{K} \times \mathrm{ET}$ & 0.0599 & 0.5199 & 0.9407 & 0.0509 & 0.9646 \\
\hline $\mathrm{K} \times \mathrm{GS}$ & 0.1055 & 0.5364 & 0.4961 & 0.0503 & 0.9822 \\
\hline ET $x$ GS & $<0.001$ & $<0.001$ & 0.0028 & 0.0617 & 0.1510 \\
\hline$S \times K \times E T$ & 0.6719 & 0.5196 & 0.4750 & 0.1421 & 0.9313 \\
\hline$S \times K \times G S$ & 0.2986 & 0.5923 & 0.3448 & 0.1008 & 0.8021 \\
\hline $\mathrm{K} \times \mathrm{ET} \times \mathrm{GS}$ & 0.0523 & 0.8752 & 0.5022 & 0.6208 & 0.8010 \\
\hline$S \times E T \times G S$ & 0.3431 & 0.2176 & 0.5323 & 0.1742 & 0.0520 \\
\hline$S \times E T \times G S \times K$ & 0.3126 & 0.3715 & 0.5290 & 0.1710 & 0.8877 \\
\hline
\end{tabular}

${ }^{*}$ Means followed by the same letter do not differ by Tukey test. ${ }^{\text {ns }}$ Means no significance.

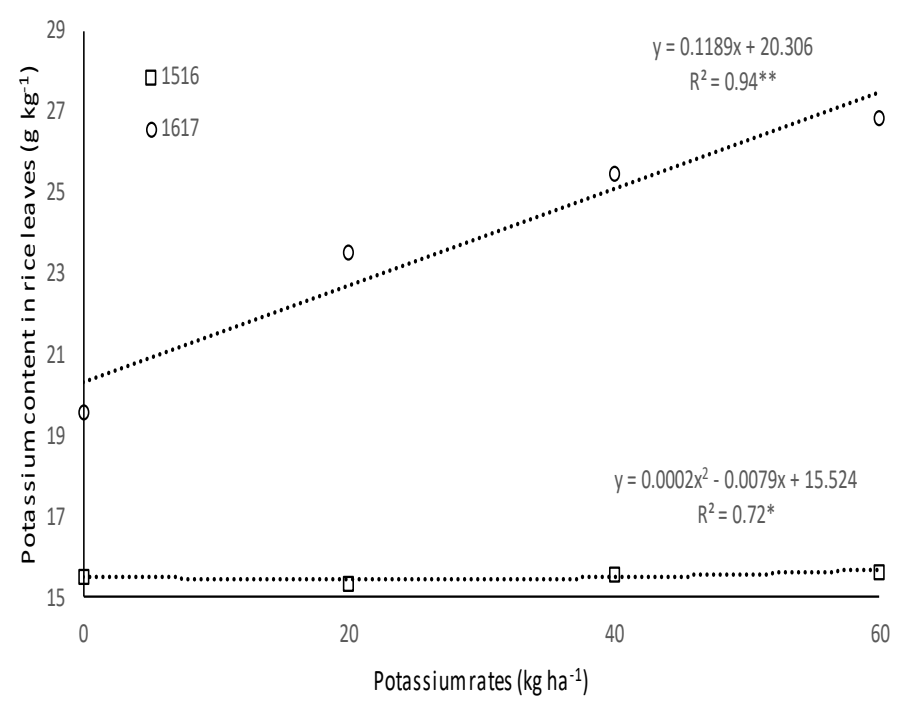

Fig 2. Potassium content in rice leaves as a function of potassium rates and growing season. Santo Antonio de Goias, GO, growing seasons 2015/16 e 2016/17. 
Table 3. Interaction between growing season and evaluation time for photosynthesis $(A)$, transpiration $(E)$, internal $\mathrm{CO}_{2}$ concentration ( $\mathrm{Ci}$ ) and leaf temperature (Tleaf) of rice plants at vegetative and reproductive phase of rice development, and with or without the use of Rhizobacterium with transpiration, stomatal conductance (gs), internal $\mathrm{CO}_{2}$ concentration and leaf temperature of upland rice plants. Santo Antônio de Goiás, growing season 2015/16 and 2016/17.

Interaction between Rhizobacterium and evaluation time

\begin{tabular}{|c|c|c|c|}
\hline \multicolumn{4}{|l|}{ Vegetative } \\
\hline & A & & Tleaf \\
\hline Rhizobacterium & $\mu \mathrm{mol} \mathrm{CO}{ }_{2} \mathrm{~m}^{-2} \mathrm{~s}^{-1}$ & & oc \\
\hline With & $26.19^{\mathrm{ns}}$ & & 29.69 a \\
\hline Without & 26.66 & & $28.75 \mathrm{~b}$ \\
\hline \multicolumn{4}{|c|}{ Reproductive } \\
\hline \multicolumn{4}{|l|}{ Rhizobacterium } \\
\hline With & $23.88 \mathrm{a}$ & & $30.32 \mathrm{~b}$ \\
\hline Without & $22.97 \mathrm{~b}$ & & $30.86 \mathrm{a}$ \\
\hline \multicolumn{4}{|c|}{ Interaction between growing season and evaluation time } \\
\hline \multicolumn{4}{|c|}{ Growing season $2015 / 16$} \\
\hline Evaluation time & $\begin{array}{c}\mathrm{A} \\
\mu \mathrm{mol} \mathrm{CO} \mathrm{m}^{-2} \mathrm{~s}^{-1}\end{array}$ & $\begin{array}{c}\mathrm{E} \\
\mathrm{mmol} \mathrm{H_{2 }} \mathrm{O} \mathrm{m}^{-2} \mathrm{~s}^{-1}\end{array}$ & $\begin{array}{c}\text { gs } \\
\mathrm{mol} \mathrm{H}_{2} \mathrm{O} \mathrm{m} \mathrm{m}^{-2} \mathrm{~s}^{-1}\end{array}$ \\
\hline Vegetative & $21.36 \mathrm{~b}$ & $4.86 \mathrm{~b}$ & $0.54^{\mathrm{ns}}$ \\
\hline Reproductive & $23.85 \mathrm{a}$ & $5.44 \mathrm{a}$ & 0.57 \\
\hline \multicolumn{4}{|c|}{ Growing season $2016 / 2017$} \\
\hline \multicolumn{4}{|c|}{ Evaluation time } \\
\hline Vegetative & $31.48 \mathrm{a}$ & $7.67 \mathrm{a}$ & $1.60 \mathrm{a}$ \\
\hline Reproductive & $23.00 \mathrm{~b}$ & $5.93 \mathrm{~b}$ & $1.30 \mathrm{~b}$ \\
\hline \multicolumn{4}{|c|}{ Interaction between growing season and Rhizobacterium } \\
\hline \multicolumn{4}{|c|}{ Growing season $2015 / 16$} \\
\hline & $\mathrm{A}$ & \\
\hline Rhizobacterium & $\mu \mathrm{mol} \mathrm{CO} \mathrm{Cm}^{-2} \mathrm{~s}^{-1}$ & \multicolumn{2}{|r|}{ vpm } \\
\hline With & $23.17 \mathrm{a}$ & \multicolumn{2}{|r|}{$271^{\text {ns }}$} \\
\hline Whiteout & $22.05 b$ & \multicolumn{2}{|r|}{265} \\
\hline \multicolumn{4}{|c|}{ Growing season 2016/17 } \\
\hline \multicolumn{4}{|l|}{ Rhizobacterium } \\
\hline$\overline{\text { With }}$ & $26.90^{\mathrm{ns}}$ & & $306 \mathrm{~b}$ \\
\hline Without & 27.59 & & $314 a$ \\
\hline
\end{tabular}

${ }^{*}$ Means followed by the same letter do not differ by Tukey test. ${ }^{\text {ns }}$ Means no significance.

Table 4. Potassium rates and Serratia spp. isolated BRM 321114 with or without inoculation in rice seeds as affecting nutrient content in rice leaves at full flowering stage. Santo Antônio de Goiás, growing season 2015/2016 and 2016/2017.

\begin{tabular}{|c|c|c|c|c|c|c|c|c|c|}
\hline Factors & $\mathrm{N}$ & $\mathrm{P}$ & $\mathrm{K}$ & $\mathrm{Ca}$ & $\mathrm{Mg}$ & $\mathrm{Cu}$ & $\mathrm{Fe}$ & $\mathrm{Mn}$ & $\mathrm{Zn}$ \\
\hline Serratia & \multicolumn{5}{|c|}{ 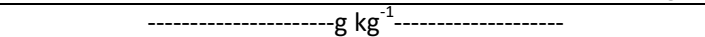 } & \multicolumn{4}{|c|}{ 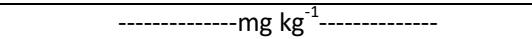 } \\
\hline With & $20.71 \mathrm{~b}$ & $3.18^{\mathrm{ns}}$ & 20.23 & 3.48 a & $2.42^{\mathrm{ns}}$ & $6.86^{\mathrm{ns}}$ & $130 \mathrm{a}$ & $75^{\mathrm{ns}}$ & $43 a$ \\
\hline Without & $22.11 \mathrm{a}$ & 3.29 & 19.18 & $3.31 \mathrm{~b}$ & 2.40 & 6.31 & $121 \mathrm{~b}$ & 71 & $40 \mathrm{~b}$ \\
\hline \multicolumn{10}{|l|}{ Growing season } \\
\hline $2015 / 2016$ & $12.36 \mathrm{~b}$ & $4.18 \mathrm{a}$ & $15.53 \mathrm{~b}$ & $2.35 \mathrm{~b}$ & $2.70 \mathrm{a}$ & $6.33^{\mathrm{ns}}$ & 185 a & $56 b$ & $64 \mathrm{a}$ \\
\hline $2016 / 2017$ & $30.46 \mathrm{a}$ & $2.29 \mathrm{~b}$ & 23.87 a & $4.43 \mathrm{a}$ & $2.11 \mathrm{~b}$ & 6.84 & $67 \mathrm{~b}$ & 89 a & $19 \mathrm{~b}$ \\
\hline Factors & \multicolumn{9}{|c|}{ ANOVA (F probability) } \\
\hline$\overline{\text { Serratia }(\mathrm{S})}$ & $<0.001$ & 0.4648 & 0.2107 & 0.0443 & 0.7086 & 0.1795 & 0.0479 & 0.4100 & 0.0495 \\
\hline Potassium rates (K) & 0.2081 & 0.3196 & 0.0169 & 0.9365 & 0.8217 & 0.4565 & 0.5427 & 0.7443 & 0.2383 \\
\hline Growing season (GS) & $<0.001$ & $<0.001$ & $<0.001$ & $<0.001$ & $<0.001$ & 0.2113 & $<0.001$ & $<0.001$ & $<0.001$ \\
\hline $\mathrm{S} \times \mathrm{K}$ & 0.2055 & 0.6517 & 0.5475 & 0.1063 & 0.3970 & 0.3042 & 0.0631 & 0.1555 & 0.4371 \\
\hline$S \times G S$ & 0.1145 & 0.0434 & 0.0914 & 0.0027 & 0.0043 & 0.6506 & 0.7487 & 0.2989 & 0.0360 \\
\hline $\mathrm{K} \times \mathrm{GS}$ & 0.1606 & 0.5236 & 0.0212 & 0.2964 & 0.8417 & 0.5555 & 0.5942 & 0.5480 & 0.2193 \\
\hline $\mathrm{S} \times \mathrm{K} \times \mathrm{GS}$ & 0.1910 & 0.4421 & 0.8057 & 0.5583 & 0.8890 & 0.5369 & 0.7774 & 0.6360 & 0.6022 \\
\hline \multicolumn{10}{|c|}{ nteraction between Rhizobacterium and growing season } \\
\hline & \multicolumn{4}{|c|}{-------Growing season 2015/2016----- } & \multicolumn{5}{|c|}{------Growing season 2016/2017------- } \\
\hline & $\mathrm{g} \mathrm{kg}^{-1}$ & $\mathrm{~g} \mathrm{~kg}^{-1}$ & $\mathrm{~g} \mathrm{~kg}^{-1}$ & $\mathrm{mg} \mathrm{kg}^{-1}$ & & & $\mathrm{~g} \mathrm{~kg}^{-1}$ & $\mathrm{~g} \mathrm{~kg}^{-1}$ & $\mathrm{mg} \mathrm{kg}^{-1}$ \\
\hline Rhizobacterium & $P$ & $\mathrm{Ca}$ & $\mathrm{Mg}$ & $\mathrm{Zn}$ & & & $\mathrm{Ca}$ & Mg & $\mathrm{Zn}$ \\
\hline With & $3.98^{\mathrm{ns}}$ & $2.29^{\mathrm{ns}}$ & $2.63^{\mathrm{ns}}$ & $67.22 \mathrm{a}$ & & & $4.66 \mathrm{a}$ & $2.21 \mathrm{a}$ & $18.30^{\mathrm{ns}}$ \\
\hline Without & 4.38 & 2.42 & 2.78 & $60.52 \mathrm{~b}$ & & & $4.20 \mathrm{~b}$ & $2.02 \mathrm{~b}$ & 18.92 \\
\hline
\end{tabular}

* Means followed by the same letter do not differ by Tukey test at $p<0.05 .{ }^{\text {ns }}$ Means no significance. 
Table 5. Potassium rates and Serratia spp. isolated BRM 321114 with or without inoculation in rice seeds as affecting plant biomass (PB), number of panicles per plant (NPP), number of grain per panicle (NGP), mass of 1000 grains (1000M) and grain yield (GY) of upland rice. Santo Antônio de Goiás, growing season 2015/2016 and 2016/2017.

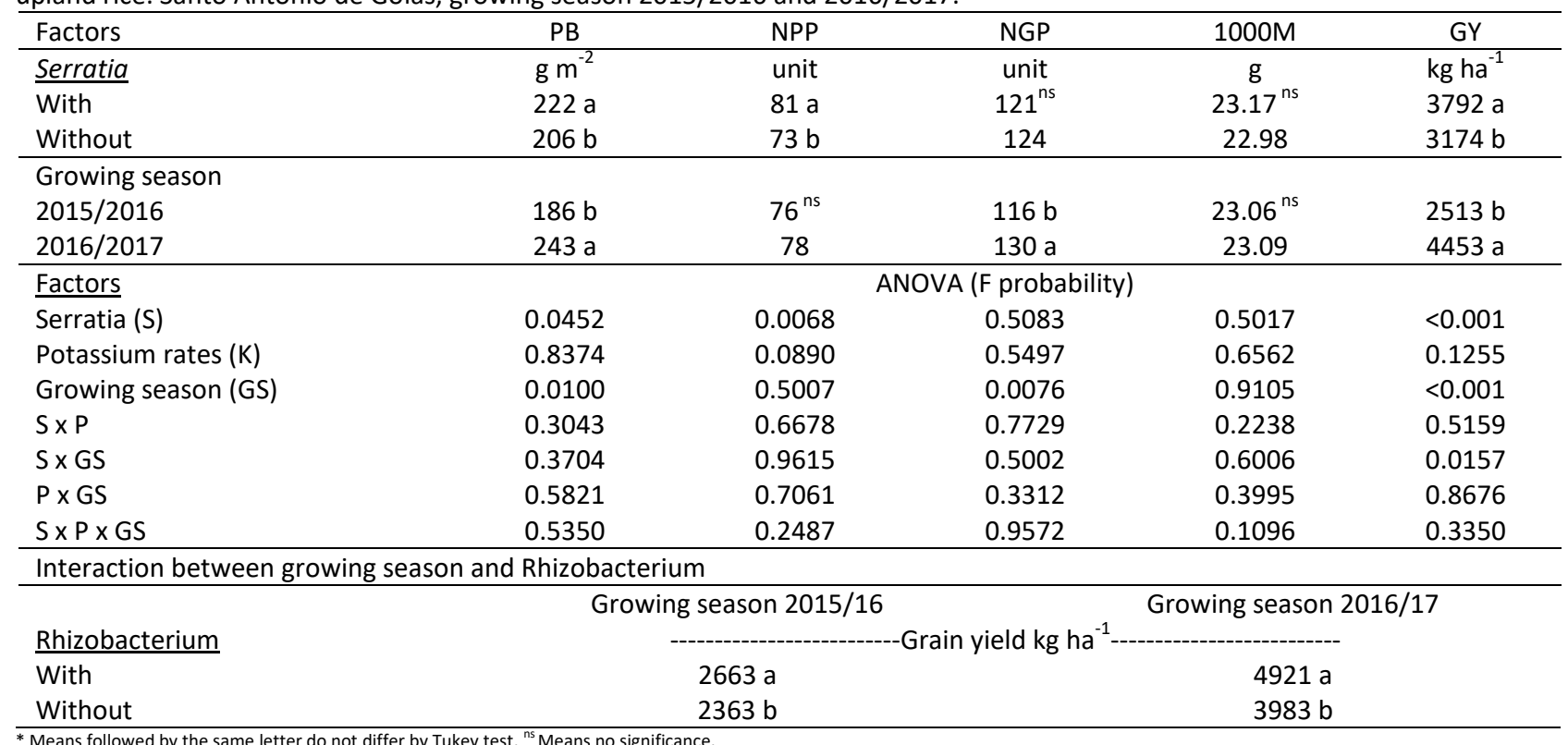

Table 6. Potassium rates and Serratia spp., strain BRM 32114, with or without inoculation in rice seeds as affecting nutrient content in rice grains. Santo Antônio de Goiás, growing season 2015/2016 and 2016/2017.

\begin{tabular}{|c|c|c|c|c|c|c|c|c|c|}
\hline Factors & $\mathrm{N}$ & $\mathrm{P}$ & $\mathrm{K}$ & $\mathrm{Ca}$ & $\mathrm{Mg}$ & $\mathrm{Cu}$ & $\mathrm{Fe}$ & $\mathrm{Mn}$ & $\mathrm{Zn}$ \\
\hline Serratia R-235 & \multicolumn{5}{|c|}{ 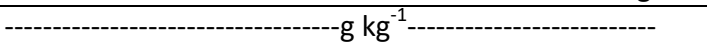 } & \multicolumn{4}{|c|}{ - } \\
\hline With & $13.18 \mathrm{~b}$ & $3.29^{\mathrm{ns}}$ & $2.61^{\mathrm{ns}}$ & $0.32^{\mathrm{ns}}$ & $1.47^{\mathrm{ns}}$ & $5.07^{\mathrm{ns}}$ & $28.10^{\mathrm{ns}}$ & $21.07^{\mathrm{ns}}$ & $34.99^{\mathrm{ns}}$ \\
\hline Without & $14.09 \mathrm{a}$ & 3.25 & 2.58 & 0.32 & 1.47 & 5.11 & 31.16 & 22.56 & 35.64 \\
\hline \multicolumn{10}{|l|}{ Growing season } \\
\hline $2015 / 2016$ & $13.39^{\mathrm{ns}}$ & $3.71 \mathrm{a}$ & $2.93 \mathrm{a}$ & $0.33 \mathrm{a}$ & $1.59 \mathrm{a}$ & $5.46^{\mathrm{ns}}$ & $31.51 \mathrm{a}$ & $19.10^{\mathrm{ns}}$ & $37.28^{\mathrm{ns}}$ \\
\hline $2016 / 2017$ & 13.96 & $2.69 \mathrm{~b}$ & $2.14 \mathrm{~b}$ & $0.31 \mathrm{~b}$ & $1.31 \mathrm{~b}$ & 4.59 & $27.13 b$ & 25.44 & 32.69 \\
\hline Factors & \multicolumn{9}{|c|}{ ANOVA (F probability) } \\
\hline 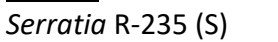 & 0.0294 & 0.4045 & 0.3053 & 0.3360 & 0.9665 & 0.3943 & 0.1515 & 0.1521 & 0.1813 \\
\hline Potassium rates (K) & 0.1104 & 0.3850 & 0.3296 & 0.1057 & 0.1026 & 0.9414 & 0.3623 & 0.4670 & 0.2235 \\
\hline Growing season (GS) & 0.1073 & $<0.001$ & $<0.001$ & $<0.001$ & $<0.001$ & $<0.001$ & 0.0097 & $<0.001$ & $<0.001$ \\
\hline$S \times K$ & 0.4771 & 0.9171 & 0.4529 & 0.2675 & 0.2094 & 0.5952 & 0.5686 & 0.1487 & 0.8679 \\
\hline$S \times G S$ & 0.4176 & 0.4712 & 0.7910 & 0.8088 & 0.2603 & 0.0070 & 0.1632 & 0.0415 & 0.0116 \\
\hline $\mathrm{K} \times \mathrm{GS}$ & 0.0885 & 0.3850 & 0.7483 & 0.0556 & 0.7472 & 0.4675 & 0.3333 & 0.7475 & 0.4088 \\
\hline$S \times K \times G S$ & 0.3713 & 0.1371 & 0.4458 & 0.0519 & 0.7780 & 0.8341 & 0.4064 & 0.9635 & 0.8826 \\
\hline \multicolumn{10}{|c|}{ Interactions between Rhizobacterium and growing season } \\
\hline & \multicolumn{5}{|c|}{ Growing season $2015 / 2016$} & \multicolumn{4}{|c|}{ Growing season $2016 / 2017$} \\
\hline Rhizobacterium & \multicolumn{3}{|l|}{$\mathrm{Cu}$} & \multicolumn{2}{|l|}{$\mathrm{Zn}$} & & $\mathrm{Mn}$ & \multicolumn{2}{|c|}{$\mathrm{Zn}$} \\
\hline With & \multicolumn{3}{|l|}{5.53} & \multicolumn{2}{|l|}{37.70} & $4.47 \mathrm{~b}$ & $23.16 b$ & \multicolumn{2}{|c|}{$31.38 \mathrm{~b}$} \\
\hline Without & 5.39 & \multicolumn{2}{|c|}{18.68} & 36.86 & \multicolumn{2}{|c|}{$4.72 \mathrm{a}$} & $27.73 \mathrm{a}$ & \multicolumn{2}{|c|}{$34.01 \mathrm{a}$} \\
\hline
\end{tabular}

${ }^{*}$ Means followed by the same letter do not differ by Tukey test. ${ }^{\text {ns }}$ Means no significance.

increased the yield components of rice grains in Cerrado Oxisol with $\mathrm{K}$ content of $82 \mathrm{mg} \mathrm{dm}$ in the soil. This value is $20 \%$ lower than the values found in our areas.

We believe that the presence of BRM 321114 with the high $\mathrm{K}$ contents in the soil provided nutrients and increased nutrient uptake ability of rice plants, especially of $\mathrm{Zn}$ (growing season 2015/16), P, Ca, and Mg (growing season 2016/17). According to Medeiros et al. (2005), plants with well-developed root systems have the ability to exploit a greater soil volume, which is fundamental for increasing the contact between roots and nutrients, resulting in an improvement in nutrient uptake.

We report that the treatment of upland rice with BRM 32114 was responsible for the positive changes observed in photosynthetic and transpiratory rates (A and $E$, respectively), stomata conductance (gs), internal $\mathrm{CO}_{2}$ concentration) during the vegetative stage (Table 2). In turn, it is also responsible for the increase in yield components (Table 4). We believe these are the result of a specific and direct interaction, generally or indirectly, or both at the same time (Pérez-Montaño et al., 2014). 
As direct effects, we know that BRM 32114 produces phytohormones, siderophores and solubilizes phosphate, as reported by Sperandio et al. (2017). These direct effects may have been responsible for the increase in the growth rate of the plants. Consequently, as an indirect effect the positive changes in the gaseous exchanges of upland rice may have been due to the supply of various nutrients to the plant, enhancing the metabolism. Some enzymes such as lipases and proteases produced by beneficial bacteria in the soil have many positive roles upon release. They can provide several nutritional substances for rice plants that increase metabolism (Sperandio et al., 2017; Nascente et al., 2017; Bandara et al., 2006). Hence, they can improve the overall biological health of the soil (Guo et al., 2008; Cassán et al., 2009; Mei and Flinn, 2010, Pérez-García et al., 2014). Sperandio et al. (2017) reported that the interaction between upland rice plants and BRM 32114 has increased the root and shoot lengths by $41.9 \%$ and $43.4 \%$. The same interaction has increased the root, shoot biomass and foliar area up to $46.5 \%, 70 \%$ and $23.64 \%$, respectively.

Our data shows that treatment with BRM 32114 changed basic metabolism such as photosynthesis no matter how much $\mathrm{K}$ was available during rice cycle. Although, to deepen and clarify the understanding knowledge on the interaction between plant and beneficial bacteria we must investigate the mechanisms used by BRM 32114, when interacting with the plant.

Along with that, higher nutrient uptake could explain in part the higher grain yield in 2016/17. For example, in 2016/17 the content of $\mathrm{K}$ in rice leaves was much higher than in 2015/16 (Fig. 2). According to Fageria (2014), a plant that grows more vigorously and consequently has higher grain yield, usually absorb more nutrients and raise their content in the leaves. On the other hand, it was observed that the higher availability of nutrients due to the presence of BRM 32114 affected the nutritional status of the shoot, but not the upland rice grain quality, with exception of $\mathrm{N}$. Besides, in the growing season 2016/2017, the experimental field has a more fertile soil (Table 1 and Sousa and Lobato, 2004) and rainfall distribution was more appropriate, since in the period from flowering to grain filling there was more rain $(370.0 \mathrm{~mm})$ than in the growing season 2015/2016 (195.4 $\mathrm{mm})$.

For $\mathrm{N}$ contents in both growing season and for $\mathrm{Cu}, \mathrm{Mn}$ and $\mathrm{Zn}$ in the growing season 2016/17, no treated plants showed higher values of these nutrients in rice grains than in growing season 2015/16. This fact could be related to the concentration effect (Fageria et al., 2011b), once in this season, the grain yield of no treated plants was significantly lower than treated plants (Table 4).

Upland rice plants with higher nutrients content reflected directly on biomass accumulation (7.2\%) and crop yield (16.3\%). Nascente et al. (2017), worked with the same cultivar and bacterial isolates and described an increase of $16.1 \%$ in rice biomass production. According to Alvarez et al. (2012), rice biomass production of plants positively correlated with crop grain yield.

Many species classified as PGPRs have been studied in order to be included in cropping systems. So, many of these PGPRs have already been commercialized, such as the genus Pseudomonas, Bacillus, Enterobacter, Klebsiella, Azobacter, Variovorax, Azospirillum, and Serratia (Glick, 2012). Our research seems promising and showed that using biodiversity (microorganism collected from the rhizosphere of upland rice) could bring many benefits to the crops systems. In this sense, using upland rice treated with beneficial microorganism could contribute to improve the profitability of the crop for the farmers, since the tested rhizobacterium provided advantages to the plant as an adequate profile of gas exchanges and availability of nutrients, independent from high $\mathrm{K}$ level in the soil. The use of microbial for integrated nutrient management of rice production can be a sustainable way of agriculture (Lavakush et al., 2014). It turns to be an environmental friendly alternative to chemical fertilizer for upland rice production as well as seems to enhance the soil fertility and health.

\section{Materials and methods}

\section{Site description}

The experiments were conducted at Capivara Experimental Station of Embrapa Rice and Beans, located at Santo Antônio de Goiás, GO, Brazil, 1628'00"S and 49017'00"W coordinates, and at $823 \mathrm{~m}$ of elevation. The climate is Tropical Savanna and is considered Aw according to its Köppen classification. There are two well-defined seasons: a usually dry season from May to September (autumn/winter) and a wet season from October to April (spring/summer). The average annual rainfall is between 1500 and $1700 \mathrm{~mm}$, and the average annual temperature is $22.7^{\circ} \mathrm{C}$, ranging annually from $14.2{ }^{\circ} \mathrm{C}$ to $34.8^{\circ} \mathrm{C}$. During the period of this study, the temperature and the amount of rainfall data were recorded (Fig. 1).

The experimental soil is classified as a clay loam (kaolinitic, thermic Typic Haplorthox) acidic soil (Embrapa, 2006). Prior to the study, in November of 2015 and 2016, chemical and physical analyses were performed according to the methodology by Donagema et al. (2011) for the initial characterization of the area (Table 1).

Experimental area had been cultivated in a program of crop rotation, named as crop-livestock integration, in a no-tillage system for five consecutive years, composed of soybean (summer, year 1), rice (summer, year 2) and irrigated common bean (winter, year 2), corn + Brachiaria (summer, year 3 ), and two years (years 4 and 5 ) of grazing pasture. The arrangement of experiments was conducted in plots where the upland rice was the crop to be grown following the established.

\section{Experimental design and treatments}

Trials were conducted in rainfed conditions using the cultivar 07SEQCL441 CL (resistant to the Imazapyr + Imazapic herbicide). Trials were arranged in a complete randomized block in a $4 \times 2$ factorial scheme with four replications, during two growing seasons (2015/16 and 2016/17) in different areas. The plots had the dimension of $3.5 \mathrm{~m} \times 6 \mathrm{~m}$. The usable area of the plot was composed of the four central rows of rice, disregarding one row of each side of the plot and $0.50 \mathrm{~m}$ to each side of the rows in each plot. The treatments consisted of combining four broadcasted $\mathrm{K}_{2} \mathrm{O}$ doses $\left(0,20,40\right.$ and $60 \mathrm{~kg} \mathrm{ha}^{-1}$ as potassium chloride) at the time of sowing with or without BRM 32114 applied on seed (microbiolization) and sprayed at plant/soil in the field at the 7 and 15 DAS (days after sowing). BRM 32114 isolate 
belongs to the Microorganism Culture Collection at the Embrapa Rice and Bean Research Center, with KX378746 GenBank code.

\section{Seed microbiolization and plant/soil spray pulverization}

BRM 32114 bacterial suspension was prepared with water using the cultures that had been growing for a 24-hour period on solid medium 523 (Kado and Heskett, 1970), at 28 ${ }^{\circ} \mathrm{C}$, and the concentration was set in a spectrophotometer to $\mathrm{A} 540=0.5\left(10^{8}\right.$ UFC). Rice seeds were immersed in the bacterial suspension for 24 hours at $25{ }^{\circ} \mathrm{C}$ under constant agitation. The control seeds (no bacteria) were immersed only in water for 24 hours in the same conditions. Soil pulverization was done at 7 days and plant pulverization at 15 days after rice sowing in all plots with rhizobacteria, with bacterial suspension prepared as described above, in the same concentration $\left(10^{8} \mathrm{UFC}\right)$, at $600 \mathrm{I} \mathrm{ha}^{-1}$, with a costal atomizer.

\section{Rice crop management}

Cover crops were desiccated with a glyphosate application (1.8 $\mathrm{kg} \mathrm{ha}^{-1}$ acid equivalent) 30 days before sowing of the upland rice. The sowing was performed mechanically using 200 seeds per $\mathrm{m}^{2}$ of rice. The seeds were sown on December $15^{\text {th }}, 2015$ and on November $23^{\text {rd }}, 2016$. Seven days before the sowing of the rice, the seed microbiolization was carried out. Rice plant emergence was occurred five days after sowing for both growing seasons. The base fertilization was applied in the sowing furrows. It was calculated according to the soil's chemical characteristics and followed the recommendations of Sousa and Lobato (2003). Therefore, the sowing fertilization was $104 \mathrm{~kg} \mathrm{ha}^{-1}$ of $\mathrm{P}_{2} \mathrm{O}_{5}+18 \mathrm{~kg} \mathrm{ha}^{-1}$ of $\mathrm{N}$ as monophosphate ammonium. The topdressing fertilization was performed 18 days after sowing using $45 \mathrm{~kg}$ $\mathrm{ha}^{-1}$ of $\mathrm{N}$ as urea in both years. Cultural practices were performed according to standard recommendations for a rice crop to keep the area free from weeds, diseases and insects.

\section{Gas exchange in rice plants}

The gas exchange was sampled from the rice plants at the vegetative and reproductive stages. Measurements were carried out using a portable gas exchange analyzer in the infrared region (LCpro+, ADC BioScientific). The parameters measured were: photosynthesis $\left(A, \mu \mathrm{mol} \mathrm{CO}_{2} \mathrm{~m}^{-2} \mathrm{~s}^{-1}\right)$, transpiration $\left(\mathrm{E}, \mathrm{mmol} \mathrm{H}_{2} \mathrm{O} \mathrm{m} \mathrm{m}^{-1}\right)$, stomatal conductance (gs, mol $\mathrm{H}_{2} \mathrm{O} \mathrm{m} \mathrm{m}^{-2}$ ), internal $\mathrm{CO}_{2}$ concentration $(\mathrm{Ci}, \mathrm{vpm})$ and leaf temperature (Tleaf, $\left.{ }^{\circ} \mathrm{C}\right)$. The readings were recorded from 08:00 to 10:00 AM, at 37 and $68 \mathrm{DAE}$ for the first growing season and 49 and 79 DAE for the second growing season.

Samples were taken in the middle third of the first fully expanded leaf (top to base) during the two evaluation periods in the two-year experiment. The equipment was set to use concentrations of $370-400 \mathrm{~mol} \mathrm{~mol}^{-1} \mathrm{CO}_{2}$ in the air, which is the reference condition used in the IRGA photosynthesis chamber. The photon flux density photosynthetic active (PPFD) was $1200 \mu \mathrm{mol}$ [quanta] $\mathrm{m}^{-2} \mathrm{~s}^{-}$ 1 . The minimum equilibration time set for performing the reading was 2 minutes.

\section{Nutrients in leaves and grains of rice}

Rice leaf samples were collected from the flag leaf at the full blooming stage. Leaves from 50 plants per plot were collected as proposed by Malavolta (2006), washed and then dried under forced-air circulation at $65^{\circ} \mathrm{C}$ for $72 \mathrm{~h}$ before grinding and analyzing the samples for chemical composition. Besides, in each plot, one sample of $100 \mathrm{~g}$ of grains was taken for nutrient analyses. In leaves and grains, the concentrations of $\mathrm{N}, \mathrm{P}, \mathrm{K}, \mathrm{Ca}, \mathrm{Mg}, \mathrm{Cu}, \mathrm{Zn}, \mathrm{Fe}$ and $\mathrm{Mn}$ were determined using methods described by Malavolta et al. (1997).

\section{Shoot dry biomass of rice plants}

Rice shoots of $1.0 \mathrm{~m}$ from one of the rows, in each plot were sampled at the full blooming stage. The shoots were washed in water and then dried in an oven with forced air circulation at $65 \circ \mathrm{C}$, then weighed to determine the shoot dry mass.

\section{Yield components and grain yield of rice}

Rice harvest was carried out by hand after physiological maturity (March $30^{\text {th }}, 2016$ and March 21 $1^{\text {st }}, 2017$ ) of the grains in the usable area of each plot. Plots were evaluated for the number of panicles $\mathrm{m}^{-1}$, which was determined by counting the number of panicles within $1.0 \mathrm{~m}$ of one of the rows in the useful area of each plot; number of grains per panicle, which was determined by counting the number of grains in 10 panicles random sampled in the usable area and divided by 10; the mass of 1000 grains, which was randomly evaluated by collecting and weighing 1000 grains from each plot, corrected to $13 \%$ of water content; and the grain yield, which was determined by weighing the harvested grain of each plot, corrected to $13 \%$ of the water content and converted to $\mathrm{kg} \mathrm{ha}^{-1}$

\section{Statistical analysis}

For statistical analysis, the SAS Statistical Software, SAS Institute, Cary, NC, USA (SAS, 1999) was used. For the qualitative factor (with or without BRM 32114), data was subjected to an analysis of variance, and when the $F$ test proved significant, the data was compared using a Tukey test at $p<0.05$. In the quantitative factor ( $K$ rates), results were submitted to regression analysis (when they were $p<0.05$ ). The blocks and all block interactions were considered as random effects. The $\mathrm{K}$ rates, use of rhizobacteria (BRM 32114) and year were considered as fixed effects.

\section{Conclusion}

The use of Rhizobacterium Serratia spp., strain BRM 32114, in the soil with high level of $\mathrm{K}$, increased the content of $\mathrm{P}, \mathrm{Ca}$, $\mathrm{Mg}, \mathrm{Fe}$ and $\mathrm{Zn}$ in rice leaves, plant biomass, number of panicles per plant, number of grains per panicle and grain yield of upland rice. Grain yield of rice treated with Rhizobacterium Serratia spp. isolate BRM 32114 was $16.3 \%$ higher than no treated plants. The use of bioagent was effective to provide better plant upland rice growth/development under field conditions and showed promising to be incorporated into crop systems. 


\section{Acknowledgments}

We thank the National Council for Scientific and Technological Development (CNPq) for a research award to the first and second authors.

\section{References}

Ahemad M, Kibret M (2014) Mechanisms and applications of plant growth promoting rhizobacteria: Current perspective. J King Saud Uni. 26: 1-20.

Anees M, Edel-Hermann V, Steinberg C (2010) Buildup of patches caused by Rhizoctonia solani. Soil Bio Biochem. 42: 1661-1672.

Baldani VLD, Baldani JI, Döbereiner J (2000) Inoculation of rice plants with the endophitic diazotrophs Herbaspirillum seropedicae and Burkholderia spp. Biol Fertil Soil. 30: 485491.

Bashan Y, de-Bashan LE, Prabhu SR, Hernandez J-P (2014) Advances in plant growth-promoting bacterial inoculant technology: Formulations and practical perspectives. Plant Soil. 378:1-33.

Choudhary DK, Sharma KP, Gaur RK (2011) Biotechnological perspectives of microbes in agro-ecosystems. Biotechnol Lett. 33:1905-1910.

Clover MW, Mallarino AP (2013) Corn and soybean tissue potassium content response to potassium fertilization and relationships with grain yield. Soil Sci Soc Am J. 77:630642.

Carmeis Filho ACA, Crusciol CAC, Nascente AS, Mauad M, Garcia RA (2017) Influence of potassium levels on root growth and nutrient uptake of upland rice cultivars. Rev Caatinga. 30:32-44.

Crusciol CAC, Fernandes AM, Filho ACAC, Alvarez RCF (2016) Macronutrient uptake and removal by upland rice cultivars with different plant architecture. Rev Bras Cienc Solo. 40:1-16

Dey R, Pal KK, Bhatt DM, Chauhan SM (2004) Growth promotion and yield enhancement of peanut (Arachis hypogeal L.) by application of plant growth-promoting rhizobacteria. Microbiol Res. 159:371-394.

Empresa Brasileira de Pesquisa Agropecuária (Embrapa) (2006) Centro Nacional de Pesquisa de Solos. Sistema brasileiro de classificação de Solos. 2. ed. Embrapa Solos, Rio de Janeiro.

Fageria NK (2009) The Use of Nutrients in Crop Plants. CRC Press, Boca Raton.

Fageria NK (2014) Mineral nutrition of rice. CRC Press, Boca Raton.

Fageria NK (2000) Potassium use efficiency of upland rice genotypes. Pesq Agrop Bras. 35:2115-2120.

Fageria NK, Baligar VC, Jones CA (2011a) Growth and mineral nutrition of field crops. 3rd edn. CRC Press, Boca Raton.

Fageria NK, Moreira A, Coelho AM (2011b) Yield and yield components of upland rice as influenced by nitrogen sources. J Plant Nutr. 34:361-370.

Fageria NK, Wright RJ, Baligar VC, Carvalho JRP (1990) Upland rice response to potassium fertilization on a Brazilian Oxisol. Fertil Res. 21:141-147.

Fageria NK, Santos AB, Moraes MF (2010) Yield, potassium uptake, and use efficiency in upland rice genotypes. Commun Soil Sci Plant Anal. 41:2676-2684.
Fageria NK, Filho MPB, Carvalho JRP (1982) Response of upland rice to phosphorus fertilization on an Oxisol of central Brazil. Agron J. 74:51-56.

Farinelli R, Penariol FG, Filho DF, Bordin L (2004) Effects of nitrogen and potassium fertilization on agronomic characteristics of upland rice cultivated under no-tillage. Rev Bras Cienc Solo. 28:447-454. In Portuguese with English abstract.

Filippi MCC, Silva GB, Silva-Lobo VL, Cortes MMCB, Moraes AJG, Prabhu AS (2011) Leaf blast (Magnaporthe oryzae) suppression and growth promotion by rhizobacteria on aerobic rice in Brazil. Biol Control. 58:160-166.

França SKS, Cardoso AF, Lustosa DC, Ramos EMLS, Filippi MCC, Silva GB (2015) Biocontrol of sheath blight by Trichoderma asperellum in tropical lowland rice. Agron Sustain Dev. 35:317-324.

Glick BR (2012) Plant Growth-Promoting Bacteria: Mechanisms and Applications. Scientifica.

Isawa T, Yasuda M, Awasaki H, Minamisawa K, Shinozaki S, Nakashita H (2010) Azospirillum sp. strain B510 enhances rice growth and yield. Microbes Environ. 25:58-61.

Kado CJ, Heskett MG (1970) Selective media for isolation of Agrobacterium, Corynebacterium, Erwinia, Pseudomonas and Xanthomonas. Phytopathology. 60:969976.

Kaschuk G, Alberton O, Hungria M (2010) Three decades of soil microbial biomass studies in Brazilian ecosystems: lessons learned about soil quality and indications for improving sustainability. Soil Bio Biochem. 42: 1-13.

Kumar V, Ladha JK (2011) Direct seeding of rice: recent developments and future research needs. Adv Agron. 111:297-396.

Malavolta E, Vitti GC, Oliveira AS (1997) Avaliação do estado nutricional de plantas: princípios e aplicações. Potafos, Piracicaba.

Malavolta E (2006) Manual de nutrição de plantas. Agron Ceres, São Paulo.

Martinez-Viveros O, Jorquera MA, Crowley DE, Gajardo G, Mora ML (2010) Mechanisms and practical considerations involved in plant growth promotion by rhizobacteria. J Soil Sci Plant Nutr. 10:293-319.

Medeiros RD, Soares AA, Guimarães RM (2005) Soil compaction and water management. I: effects upon uptake of $\mathrm{N}, \mathrm{P}, \mathrm{K}$, root and shoot dry matter of rice plants. Cienc Agrotec. 29:940-947. In Portuguese with English abstract.

Muthukumarasamy R, Cleenwerck I, Revathi G, Vadivelu M, Janssens D, Hoste B, Kang G, Park K, Young S, Tongmin S, Caballero-Mellado J (2005) Natural association of Gluconacetobacter diazotrophicus and diazotrophic Acetobacter peroxydans with wetland rice. Syst Appl Microbiol. 28: 277-286

Nascente AS, Crusciol CAC, Cobucci T (2013) The no-tillage system and cover crops - alternatives to increase upland rice yield. Eur J Agron. 45:124-131.

SAS Institute (1999) Procedure guide for personal computers. Version 5. Sas Institute, Cary.

Silva JC, Torres DB, Lustosa DC, Filippi MCC, Silva GB (2012) Rice sheath blight biocontrol and growth promotion by Trichoderma isolates from the Amazon. Rev Ciênc Agrárias. 55:243-250. 
Slaton NA, Golden BR, Norman RJ, Wilson CE, Delong RE (2009) Correlation and calibration of soil potassium availability with rice and nutritional status. Soil Sci Soc Am J. 73:1192-1201.

Sousa DMG, Lobato E (2003) Cerrado: correção do solo e adubação. Embrapa Cerrados, Planaltina.

Spaepen S, Vanderleyden J, Okon Y (2009) Plant GrowthPromoting Actions of Rhizobacteria. Adv Bot Res. 51: 284320.

Vejan P, Abdullah R, Khadiran T, Ismail S, Boyce AN (2016) Role of Plant Growth Promoting Rhizobacteria in Agricultural Sustainability-A Review. Molecules. 573:117.
Yang XE, Li H, Kirk GJD, Dobbermann A (2005) Room-induced changes of potassium in the rhizosphere of lowland rice. Commun Soil Sci Plant Anal. 36:1947-1963.

Yao LX, Wu ZS, Zheng YY, Kaleem I, Li C (2010) Growth promotion and protection against salt stress by Pseudomonas putida Rs-198 on cotton. Eur J Soil Biol. 46: 49-54.

Zaratin C, Souza SA, Pantano AC, Sá ME, Arf O, Buzetti S (2004) Effects of four potassium doses on six sprinkler irrigated rice upland cultivars. II. Outcome of grain processing. Científica. 32:115-120. In Portuguese with English abstract. 